\title{
ECONOMIC LEADING SECTORS AND COMPETITIVENESS IN SOUTH TAPANULI REGENCY
}

\author{
Tulus Hartatio Situmorang ${ }^{1)}$; Sriyoto ${ }^{2)}$; Ketut Sukiyono ${ }^{2)}$ \\ 1)Study Program of Agribusiness Faculty of Agriculture, University of Bengkulu \\ 2) Department of Agricultural Socio-Economics, Faculty of Agriculture, University of \\ Bengkulu \\ Email: 'tulushartatios@gmail.com; ${ }^{2)}$ ksukiyono@unib.ac.id
}

\begin{abstract}
How to Cite :
Situmorang, T.H, K Sukiyono, Sriyoto, 2020. Economic Leading Sectors and Competitiveness in South Tapanuli regency. Journal of Agri Socio-Economics and Business. 2 (1): 45-58. DOI: https://doi.org/10.31186/jaseb.2.1.45-58
\end{abstract}

\section{ARTICLE HISTORY \\ Received [22 May 2020] \\ Revised [08 June 2020 \\ Accepted [22 June 2020]}

\section{KEYWORDS}

leading sectors,

$L Q \& D L Q$,

shift-share,

overlay

This is an open access article under the $C C-B Y-S A$ license

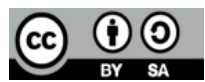

\section{ABSTRACT}

This study aims to determine the economic leading sectors, determine the position of the ecoomic leading sectors Agriculture sector specially and the priority sectors in the economic developement in South Tapanuli Regency. The data used is secondary data of the Gross Domestic Regional Bruto year 2011 to 2018 obtained from the Central Bureau of Statistic. Location Quotient (LQ), Dynamic Location Quotient (DLQ), Shift-share, and Overlay analysis were applied in this research. The result of the analysis showed that the economic leading sectors in Souths Tapanuli regency are Transportation and Warehousing sector, Other Services Activities, Agriculture, Forestry, and Fishing, Manufacturing, and Electricity and Gas sector. These sectors are also a priority order to be developed. The study showed that the Agriculture, Forestry and Fisheries sector is one of the leading sector with description: not progressive and weak competitiveness. 


\section{INTRODUCTION}

Indonesia as an agricultural country has an agricultural sector that supports national economic growth from year to year. The agricultural sector in Indonesia still have a great contribution to the national economy, which can be seen from its high annual contribution. The agricultural sector also contributes to the procurement of raw materials for the processing industry (Todaro and Smith, 2008).

Economic development in order to run optimally must have clear objectives. The three development objectives are (Todaro dan Smith, 2008). Increasing the availability and expansion of the distribution of basic necessities. 2) Increasing the standard of human life. 3) Expanding economic and social choices for each individual. However, rural areas that are still very dependent on the sustainability of agriculture, so that it controls the lives of most of the population by providing employment opportunities for people in rural areas making the agricultural sector a very strategic sector as the government's mainstay in facing the crisis (Arifin, 2004).

The agricultural sector is also a sector with the biggest contributor to GDP in the past five years in the South Tapanuli Regency where at the last year of 2017 this sector contributed 51,71\% (3.899.607,00 IDR in million Rupiahs) of total GRDP in South Tapanuli regency (Central Bureau of Statistic of South Tapanuli, 2018). It can be seen to be the largest contributor to the South Tapanuli regency's GRDP. This shows that the agricultural sector needs special attention in terms of development. The increasing trend from year to year can be used as an indication that the agriculture sector in the regency has begun to improve. This needs to be supported by a development strategy that can increase the growth of the agricultural sector in the South Tapanuli regency.

This study prioritizes the agricultural sector as the sector that will be analyzed for its position, so that in the future it can be used as a reliable sector in the regional economy which will also be able to support regional development. For this reason, it is necessary to formulate a development strategy that moves from the sub-sector that is a superior region of South Tapanuli regency. The analysis done after the result for each economic sectors obtained

\section{RESEARCH METHODS}

\section{Method of Collecting and Analysing Data}

This study used secondary data obtained from Central Bureau of Statistic publications in South Tapanuli Regency and North Sumatera Province in the form of time series data from 2011-2018.

This research used a quantitative approach using LQ, DLQ, Shift-Share analysis. These three analysis tools will be combined with the overlay analysis method to see a description of the three results of the analysis tool. The last objective 
will be answered qualitatively from the results of the analysis of the three overlays of the analysis tools.

\section{Location Quotient (LQ) Analysis}

This analysis aims to identify which subsectors are included in the leading sector. The formula used in this analysis are (Arsyad, 2010):

$$
L Q=\frac{S_{i b} / S_{b}}{S_{i a} / S_{a}}
$$

Noted: $L Q=$ Location quotient coefficient of the economic sector; Sib = production value (GRDP) of economic sector at study area ; $\mathrm{Sb}=$ total production (GRDP) of economic sector at study area (South Tapanuli regency)

The result of LQ analysis obtains two criteria, i.e., (a) LQ value $>1$ then sector $i$ is categorized as the base sector or leading sector; and (b) LQ value $<1$ then sector $i$ is categorized as non-base sector or non-leading sector.

\section{Dynamic Location Quotient (DLQ) Analysis}

Dinamic Location Quotient ( DLQ) has the same principle as static LQ, only to introduce the growth rate is the assumption that sectoral added value and GRDP have an average growth rate individually over the years (0) to years (t), while the formula for DLQ Dinc Theory (2002) as cited by Rian et al (2019) is:

$$
D L Q=\left\{\frac{\left(1+g_{i k}\right) /\left(1+g_{k}\right)}{\left(1+G_{l}\right) /(1+G)}\right\}
$$

Interpretation of DLQ is actually the same as LQ, except this comparison emphasizes the growth rate, if $D L Q=1$ means the rate growth of sector (i) to the regional GRDP growth rate (j) is proportional to the sector's growth rate in the reference region GRDP and expected to be the superior in the future. If $D L Q<1$, it means that the proportion of sector growth rate (i) to regional GRDP growth rate (j) is lower compare the proportion of the sector's growth rate to the GRDP of the reference area. Conversely, if DLQ > 1 means the proportion of the sector's growth rate (i) to regional GRDP (j) is faster than the proportion of the sector's growth rate to the reference region's GRDP. He data used is the nominal data of the GRDP.

\section{Shift-Share (SS) Analysis}

Shift share analysis is generally used to analyze the role of a sector or shift of a sector in the region to the same sector in the national economy. Data that is often analyzed is data related to economic or employment activities (Putra, 2011: 165).

The results of the analysis shift-share used in this study are from the proportional growth component (PP) and the regional share growth component 
(PPW). Calculation of the ratio value of proportional growth components and regional share growth is done using the formulation of Budiharsono (2001) in Sofiyanto (2017):

$$
P P_{i j}=\left(R_{i}-R_{a}\right) Y_{i j}
$$

Noted: PP = sector i proportional growth component for South Tapanuli regency; Ri = sector I GRDP ratio in the area of North Sumatra Province; $R a$ = ratio of GRDP in North Sumatra Province; Yij = GRDP i sector in South Tapanuli regency in the base year of analysis.

The criteria obtained from the results are : 1) If PPij $<0$, it shows that sector I in the South Tapanuli regency has a slow growth rate or not progressive. 2) If PPij $>0$, it shows that sector I in South Tapanuli regency is fast growing or progressive The next analysis in shift-share analysis is the Regional Share Growth. The formula used in this analysis is (Arsyad, 2010):

$$
P P W_{i j}=\left(r_{i}-R_{i}\right) Y_{i j}
$$

Noted: PPW $=$ Regional share growth component of the sector $i$ in South Tapanuli regency; ri = sector i GRDP ratio in South Tapanuli regency; $\mathrm{Ri}=$ sector I GRDP ratio in North Sumatra province; Yij = GRDP i sector in South Tapanuli regency in the base year of analysis.

Criteria : 1) PPW $>0$, then sector $\mathrm{i}$ in South Tapanuli regency has high/good competitiveness compared to other regions. 2) PPW $<0$, then sector $i$ in South Tapanuli regency has low/weak competitiveness compared to other regions.

\section{Overlay Analysis}

This method is used to determine the leading sectors by combining several analytical tools. In this study, overlay analysis combines three analyzes namely Location Quotient (LQ), Dynamic Location Quotient (DLQ), and analysis Shift-Share. The purpose of this overlay analysis is to see a description of potential economic activities based on contribution criteria (Location Quotient analysis), growth criteria (shift-share analysis) (Pratama, 2017).

With this method an overview of leading sectors can be obtained by providing an assessment of economic sectors seen from positive (+) and negative (-) values. The sectors that have the most positive (+) numbers mean that the sector is the leading sector and if the value of a sector has the most negative value or no positive value at all means the sector is not a leading sector (Utama, 2010). 


\section{RESULTS AND DISCUSSION}

\section{LQ \& DLQ Analysis Result}

In order to identify the leading sectors in the South Tapanuli area, LQ analysis was used as one of the methods. This analysis uses data on the contribution of each economic sector in the year of analysis of the GRDP in South Tapanuli regency and North Sumatra Province as a reference area. The results of LQ analysis of economic sectors in South Tapanuli area can be seen in the Table 1.

Table 1. The Average Value of LQ and DLQ Analysis in South Tapanuli Regency 2011-2018

\begin{tabular}{|c|c|c|c|c|}
\hline \multirow{2}{*}{ Economic Sectors } & \multicolumn{2}{|c|}{ Average Value } & \multicolumn{2}{|c|}{ Marks } \\
\hline & LQ & DLQ & LQ & DLQ \\
\hline Agriculture, Forestry, and Fishing & 1.90 & 1.00 & + & + \\
\hline Mining and Quarrying & 0.34 & 0.65 & - & - \\
\hline Manufacturing & 1.29 & 1.09 & + & + \\
\hline Electricity and Gas & 4.82 & 0.63 & + & - \\
\hline $\begin{array}{l}\text { Water Supply, Sewerage, Waste } \\
\text { Management and Remediation }\end{array}$ & 0.65 & 1.33 & - & + \\
\hline Construction & 0.01 & 1.41 & - & + \\
\hline $\begin{array}{l}\text { Wholesale and Retail Trade; Repair of } \\
\text { Motor Vehicles and Motorcycles }\end{array}$ & 0.58 & 1.57 & - & + \\
\hline Transportation and Warehousing & 1.98 & 1.32 & + & + \\
\hline $\begin{array}{l}\text { Accomodation and Food Service } \\
\text { Activities }\end{array}$ & 0.63 & 1.22 & - & + \\
\hline Information and Communication & 0.50 & 1.20 & - & + \\
\hline Financial and Insurance Activities & 0.20 & 1.38 & - & + \\
\hline Real Estate & 0.26 & 1.29 & - & + \\
\hline Business Activities & 0.21 & 1.18 & - & + \\
\hline $\begin{array}{l}\text { Public Administration and Defence; } \\
\text { Compulsory Social Security }\end{array}$ & 0.02 & 1.90 & - & + \\
\hline Education & 0.29 & 1.49 & - & + \\
\hline Human Health and Social Work Activities & 0.79 & 1.16 & - & + \\
\hline Other Services Activities & 1.46 & 1.20 & + & + \\
\hline
\end{tabular}

Source: Analysis of Secondary Data, 2020

\section{Agriculture, Forestry, and Fisheries Sector}

During the analysis period, the LQ coefficient value in the Agriculture, forestry and fisheries sectors has an LQ coefficient of 1,90 (LQ>1) which shows this sector as the leading sector. The coefficient of the DLQ result is $>1$ means this sector will also be the leading sector in the future. Agriculture has indeed become one of the 
cornerstones of the economic life of the people in South Tapanuli area. LQ coefficient 1,90 means that 1 part (of LQ value) is used to meet the needs in South Tapanuli regency itself, and the rest ( 0.90 parts) can be exported to other regions. The mainstay commodities from this district are rice and coffee bean. In 2016, there was even a rice surplus in this regency due to high production. The results of this study are in line with the research of Christina (2017) where in her research on leading sector analysis and structural transformation in Central Kalimantan Province. The results of her research indicates that the agriculture, forestry and fisheries sectors are leading sectors that need to be improved and their competitiveness strengthened.

The forestry sector in South Tapanuli regency in the past five years has experienced an increasing trend. South Tapanuli regency is a producer of forest plant commodities because forests are still large and protected and also the geographical characteristics that are the habitat of these commodities. Forest products such as processed forest wood products, plywood, and essential oils are a source of income from the forestry sector in the South Tapanuli area.

The development of freshwater aquaculture which in recent years has been increasingly encouraged to begin showing results. Citing from the antarasumut.com, many parties are increasingly promoting freshwater fish farming in the South Tapanuli area. Some of the major projects that exist include community coaching by NSHE that previously had conflicts with residents and environmental activists about the development of existing hydropower projects. Freshwater fish species that are fostered in this activity are Jurung fish or better known as Batak fish among the people of North Sumatra. Other cultivation activities are catfish farming initiated by IPK (Ikatan Pemuda Karya), South Tapanuli regency.

\section{Manufacturing Sector}

This sector, for the category of food and beverage processing, can be linked as a result of the launching of the South Tapanuli regency Head's 2009 program. The program is about promoting the manufacturing industry in the form of a home industry in South Tapanuli regency. As one of the zalacca-producing regions, since the program was launched, zalacca processing has been increasingly carried out by business activist communities. Salak-based processed products are increasingly being developed until now we can find various types of processed products made from salak from South Tapanuli namely Salak Chips, Salak Dodol, Salak Syrup, Kurma Salak, and Sambal Salak. The more developed types of processed products produced shows how market opportunities for processed products like this are indeed very promising.

The step taken by the government in the realization of the development of MSME is to facilitate business actors in obtaining business licenses and also BPOM certification which is also accompanied without ignoring the existing standardization and in accordance with existing regulations. 


\section{Electricity and Gas Sector}

Simply stated, the more the development of the processing industry growth the more this sector also giving the contribution to the GRDP in the Regency making this sector is also one of the leading sectors in the South Tapanuli regency. The average use of electricity and gas in the processing industry has indeed become one of the most dependable supporting factors in the processing industry. The existence of this sector as one of the base sectors is also due to the $4 \times 127.5 \mathrm{MW}$ capacity of the Hydropower Batangtoru development project since 2015. This project also brought in FDI to South Tapanuli regency reaching Rp. 5.8 Trillion from a total of 16.45 trillion in total PMA in North Sumatra Province. This clearly shows the position of this sector in the economy of South Tapanuli regency (antaranews.com).

The two sectors have an inseparable relationship (processing industry and electricity and gas). The increasing number of processing industries is accompanied by the increasing use of electricity and gas in the processing process in the industry as well as the use of gas.

\section{Transportation and Warehousing}

Transportation is one of the infrastructures that is a milestone in the mobility of the community, both individuals and in the distribution of goods and services. This sector has become a leading sector in South Tapanuli regency according to the LQ value of 1.98, which is greater than one. Eventhough nationally, the growth of the transportation and warehousing sector has slowed, but it still contributes greatly to GNP (bisnis.com).

This sector became the leading sector in South Tapanuli regency during the analysis period, which can be attributed to the increasingly fierce development and industrial activities in the South Tapanuli area. The results of this study are the same as Darwin's (2017) study entitled the analysis of leading sectors in the development of the Meranti islands district. His research shows that the leading economic sector is the transportation and warehousing sector.

The development of the South Tapanuli regency industry which started life since 2009 is the salak canning industry, the Plywood and processed forest wood industry, the cooking oil industry and the palm oil processing factory, the banana processing industry, the processed rubber wood industry, the palm oil processing factory and rubber wood processing, corn production, cooking oil and chemical oil processing (North Sumatra in Figures, 2011).

\section{Other Service Activities}

Other services available in South Tapanuli regency refer to South Tapanuli Central Bureau of Statistic publications for service providers such as arts, entertainment and recreation. In the year of analysis, indeed recreation activities, both natural and urban-based entertainment sites are being built. Nature tourism recreation such as Aek Sijorni, Silima-lima Waterfall is also a mainstay of the 
recreation arena for the people of South Tapanuli which certainly opens opportunities for economic transaction activities to occur in the recreation site and its surroundings.

\section{Shift-Share (SS) Analysis Result}

The economic sectors that have the highest proportional growth value are agriculture, forestry, and fisheries. This shows that the growth of the agriculture, forestry and fisheries sectors is the highest. A sector that has a positive PPij value means that the sector has fast sector growth, while a sector with a negative PPij value indicates that the sector has a slow growth rate. The high value of the PP component means the high growth while the negative mark means the growth of this sector is slow or not progressive. Based on Pratiwi's research (2019) this was caused by an indication of a shift in the economic sector from the agricultural sector to the nonagricultural sector. Hence, the growth of the sector is slow beacuse of the indication of the shifting.

The PP value of each economic sector in South Tapanuli regency is diverse. The negative sign of PP value indicates that the economic sector is included in the category not progressive. From the five basic sectors resulting from the LQ analysis, the transportation and warehousing sector and other service sectors are classified as advanced or progressive sectors.

The interesting fact about the results of this analysis is the processing sector. The manufacturing industry sector has the lowest PPij value of $77.7 \%$ with a negative value which means the slowest growth of this sector. This is understandable where MSMEs have begun to be programmed in this analysis area since 2009. However, growth can only be seen in the final year of analysis, where the amount of GRDP provided by this sector is indeed very high and has become a base sector.

Based on the results of the analysis of regional share growth, the economic sectors in the analysis area also have different values. PPW value> 0 means that the sector has good competitiveness compared to other sectors. Whereas sectors with PPW value $<0$ indicate that the sector has poor competitiveness (Budiharsono, 2005).

From the table, leading sectors based on LQ analysis have low competitiveness, namely the agriculture, forestry and fisheries sector, the manufacturing sector, and the Electricity and Gas Sector. The transportation and warehousing sector, and other service sectors have a good competitiveness. 
Table 2. $\quad$ Shift-share Value of Economic Sectors in South Tapanuli Regency 2011 2018

\begin{tabular}{lrr}
\hline & \multicolumn{2}{c}{ Shift-Share } \\
\cline { 2 - 3 } \multicolumn{1}{c}{ Economic Sectors } & $\begin{array}{c}\text { Proportional } \\
\text { Growth } \\
\text { (Million IDR) }\end{array}$ & $\begin{array}{c}\text { Regional Share } \\
\text { Growth (Million IDR) }\end{array}$ \\
\hline Agriculture, Forestry, and Fishing & $-190,401.82$ & $-373,611.26$ \\
Mining and Quarrying & $10,906.10$ & $-41,120.40$ \\
Manufacturing & $-196,136.31$ & $-1,230,590.59$ \\
Electricity and Gas & $-11,206.22$ & $-49,365.35$ \\
Water Supply, Sewerage, Waste & -34.36 & $1,889.91$ \\
Management and Remediation & 359.15 & $1,014,034.45$ \\
Construction & $19,382.46$ & $114,814.65$ \\
Wholesale and Retail Trade; Repair of & $62,843.96$ & $-817,059.65$ \\
Motor Vehicles and Motorcycles & $12,129.84$ & $-4,557.88$ \\
Transportation and Warehousing & $19,121.37$ & $-73,148.65$ \\
Accomodation and Food Service Activities & $-1,859.49$ & $24,877.90$ \\
Information and Communication & $4,592.63$ & $92,079.17$ \\
Financial and Insurance Activities & $1,042.92$ & $-12,512.38$ \\
Real Estate & -364.49 & $533,605.55$ \\
Business Activities & 727.97 & $16,765.86$ \\
Public Administration and Defence; & $10,474.80$ & -715.49 \\
Compulsory Social Security & $3,539.51$ & $-64,169.90$ \\
Education & $-252,503.39$ & $-868,784.05$ \\
Human Health and Social Work Activities & &
\end{tabular}

Source: Analysis of Secondary Data, 2020

\section{Overlay Result Analysis}

Overlay analysis is done by combining the results of the analysis of the three analytical tools that have been used. Based on the results of this analysis, it can be used to view descriptions of potential economic activities. The results of overlay analysis can be seen in Table 4 .

Table 3. Overlay of Location Quotient (LQ), Dynamic Location Quotient (DLQ), and Shift-share analysis in South Tapanuli Regency 2011 - 2018

\begin{tabular}{llll} 
Economic Sectors & LQ DLQ & $\begin{array}{l}\text { Shift- } \\
\text { Share }\end{array}$ \\
\cline { 3 - 3 } PG RSG
\end{tabular}

Descriptions 


\begin{tabular}{|c|c|c|c|c|c|}
\hline $\begin{array}{l}\text { Agriculture, Forestry, } \\
\text { and Fishing }\end{array}$ & $>1$ & + & - & - & $\begin{array}{l}\text { Leading Sector, not progressive, weak } \\
\text { competitiveness }\end{array}$ \\
\hline Mining and Quarrying & $<1$ & - & + & - & $\begin{array}{l}\text { Mainstay sector,Progressive, weak } \\
\text { competitiveness }\end{array}$ \\
\hline Manufacturing & $>1$ & + & - & - & $\begin{array}{l}\text { Leading Sector, not progressive, weak } \\
\text { competitiveness }\end{array}$ \\
\hline Electricity and Gas & $>1$ & - & - & - & $\begin{array}{l}\text { Mainstay Sector, not progressive, } \\
\text { weak competitiveness }\end{array}$ \\
\hline $\begin{array}{l}\text { Water Supply, Sewerage, } \\
\text { Waste Management and } \\
\text { Remediation }\end{array}$ & $<1$ & + & - & + & $\begin{array}{l}\text { Mainstay Sector, not progressive, } \\
\text { good competitiveness }\end{array}$ \\
\hline Construction & $<1$ & + & + & + & $\begin{array}{l}\text { Mainstay sector, Progressive, good } \\
\text { competitiveness }\end{array}$ \\
\hline $\begin{array}{l}\text { Wholesale and Retail } \\
\text { Trade; Repair of Motor } \\
\text { Vehicles and } \\
\text { Motorcycles }\end{array}$ & $<1$ & + & + & + & $\begin{array}{l}\text { Mainstay sector, Progressive, good } \\
\text { competitiveness }\end{array}$ \\
\hline $\begin{array}{l}\text { Transportation and } \\
\text { Warehousing }\end{array}$ & $>1$ & + & + & - & $\begin{array}{l}\text { Leading sector, Progressive, weak } \\
\text { competitiveness }\end{array}$ \\
\hline $\begin{array}{l}\text { Accomodation and Food } \\
\text { Service Activities }\end{array}$ & $<1$ & + & + & - & $\begin{array}{l}\text { Mainstay sector, Progressive, weak } \\
\text { competitiveness }\end{array}$ \\
\hline $\begin{array}{l}\text { Information and } \\
\text { Communication }\end{array}$ & $<1$ & + & + & & $\begin{array}{l}\text { Mainstay sector, Progressive, weak } \\
\text { competitiveness }\end{array}$ \\
\hline $\begin{array}{l}\text { Financial and Insurance } \\
\text { Activities }\end{array}$ & $<1$ & + & - & + & $\begin{array}{l}\text { Mainstay sector, Not progressive, } \\
\text { good competitiveness }\end{array}$ \\
\hline Real Estate & $<1$ & + & + & + & $\begin{array}{l}\text { Main sector, Progressive, good } \\
\text { competitiveness }\end{array}$ \\
\hline Business Activities & $<1$ & + & + & - & $\begin{array}{l}\text { Mainstay sector, Progressive, weak } \\
\text { competitiveness }\end{array}$ \\
\hline $\begin{array}{l}\text { Public Administration } \\
\text { and Defence; } \\
\text { Compulsory Social } \\
\text { Security }\end{array}$ & $<1$ & + & - & + & $\begin{array}{l}\text { Mainstay sector, Not } \\
\text { progressive,goodcompetitiveness }\end{array}$ \\
\hline Education & $<1$ & + & + & + & $\begin{array}{l}\text { Main sector, Progressive, good } \\
\text { competitiveness }\end{array}$ \\
\hline $\begin{array}{l}\text { Human Health and } \\
\text { Social Work Activities }\end{array}$ & $<1$ & + & + & - & $\begin{array}{l}\text { Main sector, Progressive, weak } \\
\text { competitiveness }\end{array}$ \\
\hline Other Services Activities & $>1$ & + & + & - & $\begin{array}{l}\text { Leading sector, Progressive, weak } \\
\text { competitiveness }\end{array}$ \\
\hline
\end{tabular}

Source: Analysis of Secondary Data, 2020

\section{Leading Sector, Progressive, and low competitiveness}

Two sectors that incuded into this category are the transportation and warehousing sector and other service sectors. Both of these sectors are the leading sectors in the analysis area, but they are not competitive compared to the same sector in other regions in North Sumatra province. This result is the same as Dewi 
(2018) where it is concluded that the transportation and warehousing sector is the first priority in economiy development in Karangasem Regency. This sector is increasing due to the increasing need of the community for transportation services for mobility and warehousing that will provide efficiency.

\section{Leading Sector, not Progressive, and weak competitiveness}

The agriculture, forestry and fisheries sector, the manufacturing industry sector, and the Electricity and Gas Sector fall into this category where this sector is the leading sector in South Tapanuli regency which is not progressive and has no competitiveness compared to the same sector in other regions in the province North Sumatera, as presented in Table 3. Compared with the research of Riantika (2017) the Agriculture, forestry and fisheries sector in the gianyar regency is in the fourth list of the priority development. This is due to the decreasing in agricultural land in the analysis area each year. However, the result of this research can be related to the indication of a shift in the economy from the agricultural sector to the nonagricultural sector.

\section{Priority in Developing the Leading Sectors}

Based on the results of the overlay of LQ, DLQ, and Shift-Share over economic sectors in South Tapanuli regency, in compiling priorities in the development of the economic sector is done by looking at the positive value of each leading sector (Hajeri, 2015). So that the priorities for developing the economic sector in South Tapanuli regency are:

1. Transportation and warehousing sector are the main priorities in the economic development of South Tapanuli regency. This is because the results of the analysis which indeed illustrates the contribution of this sector to the South Tapanuli regency's GRDP also from the growth rate of this sector are indeed more progressive than other leading sectors.

2. Other Services Sector is the second priority in developing the economic sector in South Tapanuli regency. Although based on the results of the analysis of this sector and the transportation and warehousing sector have the same description, but for consideration, the total contribution of this sector is still smaller than the contribution of the Transportation and Warehousing sector. So that this sector is right made as the second development priority.

3. The third development priority is the agriculture, forestry and fisheries sectors. This sector is the sector with the largest number of contributions to GRDP South of Tapanuli regency. However, based on the results of the analysis of position and competitiveness, this sector is a sector that is not progressive and has no competitiveness, so further studies are needed concerning this sector specifically. 
4. The development of the economic sector in South Tapanuli regency in the fourth priority is the manufacturing sector. Furthermore, the alternative sector is the Electricity and Gas Sector. These two sectors are the sectors described previously as interconnected sectors. These two sectors are included in the fourth and alternative priorities.

\section{CONCLUSIONS AND RECOMENDATIONS}

\section{Conclusions}

Based on the results and discussion, the conclusions that can be obtained in this study are: Sectors that are leading sectors in the economy of South Tapanuli regency, namely: Agriculture, Forestry, and Fisheries Sector; Manufacturing Industry Sector; Electricity and Gas Sector; Transportation and Warehousing Sector; and Other Service Sectors.

The Agriculture Sector in South Tapanuli regency has a slow but increasing growth. The agricultural sector in the Agriculture Regency also plays an important role in the economy of South Tapanuli regency, which can be seen from the LQ value of the agricultural sector, namely $1.90($ LQ> 1$)$ and DLQ $=1(+)$. This defines the agricultural sector as one of the sectors that will remain a superior.

Formulation of economic sector development priorities in maximizing the contribution of each leading sector in South Tapanuli regency, namely: 1. Transportation and Warehousing Sector, 2. Other Service Sector, 3. Agriculture, Forestry and Fisheries sector, 4. Manufacturing Industry sector,5. Electricity and Gas Sector (Alternative Priority).

\section{Recommendations}

The position of the agricultural sector based on the analysis of proportional growth and share of the region, including the growth of this sector is slow and has no competitiveness. Based on this, it is very possible to be increased again. The effort that can be done is by the government more specifically making a study of this matter and by formulating solutions that can be done by involving each stakeholder in the Agriculture Office in South Tapanuli regency. Further research focused on the Agriculture, Forestry, and Fisheries sector is strongly reccomended. 


\section{REFERENCES}

Arifin, Bustanul. 2004. Analisis Ekonomi Pertanian Indonesia. PT Kompas Media Nusantara, Jakarta.

Arsyad, L. 2010. Ekonomi Pembangunan. STIE. Yayasan Keluarga Pahlawan. Yogyakarta.

Budiharsono, S., 2005. Teknik Analisis Pembangunan Wilayah Pesisir dan Lautan. Pradnya Paramita. Jakarta.

Hajeri, Erlinda Y., Eva D. 2015. Analisis Penentuan Sektor Unggulan Perekonomian di Kabupaten Kubu Raya. Jurnal Ekonomi dan Bisnis dan Kewirausahaan. 4(2):253-269.

Hidayat, M. Darwin. 2017, Analisis Sektor unggulan dalam pengembangan wilayah kabupaten kepulauan meranti. Media Trend 12(2):156-167

Ida Bagus Adytia Riantika, Made S.U. 2017. Penentuan Prioritas Pembangunan Melalui Alnalisis Sektor - Sektor Potensial di Kabupaten Gianyar. E-Journal Ekonomi Pembangunan Universitas Udayana. 6(7):1185-1211.

Ilham Budiman."Sektor Transportasi Pergudangan Melambat Pengusaha Optimistis".https://ekonomi.bisnis.com/read/20181106/98/857124/sektortransportasi-pergudangan-melambat-pengusaha-optimistis. (diakses 29 Agustus 2019)

Kodir Pohan. 2019. "IPK Tapanuli Selatan Bangun Wirausaha Anggota Lewat Budidaya lelejumbo".https://sumut.antaranews.com/berita/189822/ipktapanuli-selatan-bangun-wirausaha-anggota-lewat-budidaya-lelejumbo.(diakses 29 Agustus 2019)

Kodir Pohan."Tapanuli Selatan Surplus Beras 84 Ton Lebih".https://sumut.antaranews.com/berita/164073/2016-tapanuliselatan-surplus-beras-84-ton-lebih.(diakses 29 Agustus 2019)

Maria C., Yuli P. 2017. Analisis Sektor Unggulan dan Transformasi Struktural di Provinsi Kalimantan Tengah 2010 - 2016. Jurnal KELITBANGAN. 5(3):184205.

Maria Christina Yuli Pratiwi. 2019. Analysis of economic structure shift and potency of leading sector of kotawaringin timur regency. Jurnal Pembangunan Nagari 4(2):202-2019.

Ni Made Winda Savitri Dewi, I Nyoman M.Y. 2018. Analisis Sektor Potensial dalam menetapkan perencanaan Pembangunan di Kabupaten Karangasem. EJournal Ekonomi Pembangunan Universitas Udayana. 7(1):152-183.

Pratama, A.R, Sukiyono, K., Aranti, N.N. 2017. Analisis Subsektor Pertanian Unggulan Kabupaten/Kota di Provinsi Provinsi Bengkulu. AGRIC Jurnal IImu Pertanian. 29(2):121-136.

Putra, M.F.2011. Studi Kebijakan Publik dan Pemerintahan dalam Perspektif Kuantitatif. Universitas Brawijaya (UB) Press. Cetakan Pertama. April 2011. Malang. 
Rian D. et al. 2019. Food Commodity Competitiveness and Accessibility in Barlingmascakeb. JEJAK Journal of Economics and Policy. 12(1):218-237

Todaro, Michael P, dan Stephen C. Smith. 2008. Pembangunan Ekonomi. Jakarta: Erlangga

Utama, S. Made, I. 2010. Buku Ajar Ekonomi Regional. Denpasar:Fakultas Ekonomi Universitas Udayana 